\title{
The effects of small-scale, homelike facilities for older people with dementia on residents, family caregivers and staff: design of a longitudinal, quasi-experimental study
}

\author{
Hilde Verbeek*1, Erik van Rossum ${ }^{1}$, Sandra MG Zwakhalen ${ }^{1}$, \\ Ton Ambergen ${ }^{2}$, Gertrudis IJM Kempen ${ }^{1}$ and Jan PH Hamers ${ }^{1}$
}

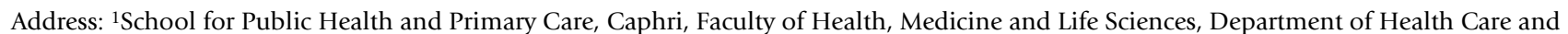
Nursing Science, Maastricht University, Maastricht, the Netherlands and ${ }^{2}$ School for Public Health and Primary Care, Caphri, Faculty of Health, Medicine and Life Sciences, Department of Methodology and Statistics, Maastricht University, Maastricht, the Netherlands

Email: Hilde Verbeek* - h.verbeek@zw.unimaas.nl; Erik van Rossum - erik.vanrossum@zw.unimaas.nl; Sandra MG Zwakhalen - s.zwakhalen@zw.unimaas.nl; Ton Ambergen - ton.ambergen@stat.unimaas.nl; Gertrudis IJM Kempen - g.kempen@zw.unimaas.nl; Jan PH Hamers - jph.hamers@zw.unimaas.nl

* Corresponding author

Published: 20 january 2009

BMC Geriatrics 2009, 9:3 doi:10.1186/147I-2318-9-3

This article is available from: http://www.biomedcentral.com/l47I-23I8/9/3

(c) 2009 Verbeek et al; licensee BioMed Central Ltd.

This is an Open Access article distributed under the terms of the Creative Commons Attribution License (http://creativecommons.org/licenses/by/2.0), which permits unrestricted use, distribution, and reproduction in any medium, provided the original work is properly cited.

\begin{abstract}
Background: Small-scale and homelike facilities for older people with dementia are rising in current dementia care. In these facilities, a small number of residents live together and form a household with staff. Normal, daily life and social participation are emphasized. It is expected that these facilities improve residents' quality of life. Moreover, it may have a positive influence on staff's job satisfaction and families involvement and satisfaction with care. However, effects of these small-scale and homelike facilities have hardly been investigated. Since the number of people with dementia increases, and institutional long-term care is more and more organized in small-scale and homelike facilities, more research into effects is necessary. This paper presents the design of a study investigating effects of small-scale living facilities in the Netherlands on residents, family caregivers and nursing staff.
\end{abstract}

Methods and design: A longitudinal, quasi-experimental study is carried out, in which 2 dementia care settings are compared: small-scale living facilities and regular psychogeriatric wards in traditional nursing homes. Data is collected from residents, their family caregivers and nursing staff at baseline and after 6 and 12 months of followup. Approximately 2 weeks prior to baseline measurement, residents are screened on cognition and activities of daily living (ADL). Based on this screening profile, residents in psychogeriatric wards are matched to residents living in small-scale living facilities. The primary outcome measure for residents is quality of life. In addition, neuropsychiatric symptoms, depressive symptoms and social engagement are assessed. Involvement with care, perceived burden and satisfaction with care provision are primary outcome variables for family caregivers. The primary outcomes for nursing staff are job satisfaction and motivation. Furthermore, job characteristics social support, autonomy and workload are measured. A process evaluation is performed to investigate to what extent small-scale living facilities and psychogeriatric wards are designed as they were intended. In addition, participants' satisfaction and experiences with small-scale living facilities are investigated.

Discussion: A longitudinal, quasi-experimental study is presented to investigate effects of small-scale living facilities. Although some challenges concerning this design exist, it is currently the most feasible method to assess effects of this relatively new dementia care setting. 


\section{Background}

It is estimated that around 24 million people suffered from dementia worldwide in 2001 and this number will double every 20 years [1]. Most people suffering from dementia are cared for at home, but institutional care is often inevitable as the disease progresses. Institutional dementia care is increasingly organized in small-scale and homelike facilities. These are facilities in which a small number of residents live together in a homelike environment. Normalization of daily life with person-centered care is a central theme in these facilities [2]. In the literature, this care concept is also referred to as a 'home' model [3] or 'housing' model [4] as opposed to the medical model of care. Traditionally, institutional care for people with dementia has been organized to this medical model $[5,6]$ and this has resulted in large-scale institutional nursing homes. Nowadays, policy principles emphasize that institutional care should be as homelike as possible [7]. Small-scale and homelike facilities are the result of this shift in dementia care concept. Differences with traditional nursing homes exist at a physical, social and organizational level. Table 1 presents a summary of main differences [3,8-10].

In many countries small-scale and homelike facilities have been established, such as group living in Sweden [11], Green Houses in the United States [12] and residential groups in Germany [13]. In the Netherlands, there is nowadays a large increase of small-scale living facilities, also referred to as group living [10]. It is expected that in 2010 , approximately $25 \%$ of Dutch nursing home care for older people with dementia is organized in small-scale living facilities. In Sweden, almost 20\% $(14,000)$ of people with dementia residing in institutional care lived in group living facilities in 2000 [14].

Despite these developments, little is known yet about effects of a small-scale and homelike environment on residents, family and professional caregivers [2]. Some stud- ies [15-18] report positive findings for residents. It is suggested that residents in small and homelike facilities have a better mobility [15], more social capacities [16] and a higher quality of life $[17,18]$ than residents living in traditional nursing homes. However, more behavioral problems have also been reported for residents in small, homelike facilities [19]. Family members in small-scale living facilities appear to be more satisfied with care [20] and seem to experience less burden than family in traditional nursing homes [21]. Findings from staff members indicate that they may have a higher job satisfaction and motivation than in traditional nursing home care $[22,23]$, although negative results such as a higher workload have also been reported [22].

Most studies regarding the effects of small-scale living facilities for older people with dementia suffer from several methodological limitations, such as inclusion of a small number of residents [15], no follow-up measurements [19], differences at baseline between residents in small-scale living and traditional nursing home care [17] or no control group at all. These drawbacks limit the interpretation of results. Since the number of people with dementia will increase worldwide $[1,24]$ and dementia care will be more and more organized in small-scale and homelike facilities, more research and knowledge regarding effects of this environment is necessary.

\section{Aim and research questions}

The current paper presents the design of a Dutch longitudinal, quasi-experimental study, investigating the effects of small-scale living facilities for older people with dementia. Residents, their family and nursing staff of small-scale living facilities are compared with those living in regular psychogeriatric wards of traditional nursing homes on several outcome measures. The three research questions are:

Table I: Physical, social and organizational characteristics: traditional nursing homes vs. small-scale living facilities.

\begin{tabular}{|c|c|c|}
\hline & Traditional nursing home & Small-scale living facility \\
\hline Physical & $\begin{array}{l}\text { - Large-scale wards } \\
\text { (>20 residents) } \\
\text { - Long corridors } \\
\text { - Institutional character }\end{array}$ & $\begin{array}{l}\text { - Small units } \\
(6-8 \text { residents }) \\
\text { - Homelike character, based on a archetype house }\end{array}$ \\
\hline Social & $\begin{array}{l}\text { - Many fellow residents and nursing staff working at one } \\
\text { ward }\end{array}$ & $\begin{array}{l}\text { - Emphasis on family situation } \\
\text { - Residents form a group } \\
\text { - Nursing staff is part of the household }\end{array}$ \\
\hline Organizational & $\begin{array}{l}\text { - more 'Top-down': organization/nursing home decides } \\
\text { daily routine } \\
\text { - Task-differentiation: many different functions and staff }\end{array}$ & $\begin{array}{l}\text { - more 'bottom-up': residents and family caregivers have a large } \\
\text { influence on daily routine } \\
\text { - Nursing staff have integrated tasks: i.e. medical, personal care, } \\
\text { activities and household }\end{array}$ \\
\hline
\end{tabular}


1. What are the effects of small-scale living facilities on residents' quality of life, behavioral problems and social engagement?

2. What are the effects of small-scale living facilities on family caregivers' involvement, satisfaction with care delivery and perceived burden from informal care?

3. What are the effects of small-scale living facilities on staff's job satisfaction, motivation and work perception, such as perceived social support, autonomy and burden?

In addition, a process evaluation is performed with 2 main goals: 1) to investigate to what extent both types of dementia care settings are designed as they were intended and 2) to investigate participants' satisfaction and experience with small-scale living facilities.

\section{Methods and design}

A longitudinal, quasi-experimental study is carried out (April 2008 - January 2010). Two types of dementia care settings are compared: small-scale living facilities (experimental group) and psychogeriatric wards in traditional nursing homes (control group). Outcome measures regarding residents, family care givers and nursing staff are measured at three moments in time: a baseline measurement (T1) and after 6 (T2) and 12 months (T3) after baseline. To enhance comparability of groups at baseline, residents are matched, using a screening procedure approximately 2 weeks prior to T1. Figure 1 presents a flow chart of the design and data collection. In addition to the effect study, a process evaluation is performed.

The study design and protocols are approved by the Medical Ethics Committee of the University Hospital Maastricht and Maastricht University. In addition, local Ethical Committees of participating institutions have given their consent to the study protocols and procedures.

\section{Target population}

The target populations of this study are older people with dementia, who receive institutional nursing home care, their family caregivers and nursing staff working at their unit. They are recruited in two types of dementia care settings: small-scale living facilities and psychogeriatric wards in traditional nursing homes, all in the southern part of the Netherlands.

\section{Residents}

All residents in small-scale living facilities are eligible for participation in this study, if they 1) have a primary diagnosis of dementia, based on criteria established by the Diagnostic and Statistical Manual of Mental Disorders, fourth edition [25] and 2) have been living in the care setting for at least 4 weeks prior to data collection. The type and severity of the dementia syndrome may vary. Residents with a primary psychiatric disease or those with Korsakoff's syndrome are excluded, because they usually differ from other residents with dementia (e.g. have a better mobility and are younger) and live often in special wards. Residents living in psychogeriatric wards in traditional nursing homes are eligible if they meet the above mentioned criteria and in addition match the cognition and ADL-profile of residents in small-scale living facilities. This is assessed in a screening prior to the baseline measurements.

\section{Family caregivers}

A family caregiver is in this study defined as someone who has or takes the responsibility for a resident with dementia at a voluntary basis. All main family caregivers providing informal care for participating residents in this study are eligible. The number is limited to one main family caregiver per resident.

\section{Staff}

All nursing staff (i.e. nursing assistants, certified nursing assistants and registered nurses) working on a permanent basis in either the selected small-scale living facilities or regular psychogeriatric wards in which the residents live are eligible to participate in the study. Temporary staff, such as trainees, are excluded from the study.

\section{Small-scale living facilities: experimental group}

Small-scale living facilities had to fulfill the following criteria to be eligible for this study:

1. A maximum of 8 residents per house or unit. This number is considered in the Netherlands as a maximum number for small-scale living [10].

2. Staff, residents and their family form a household together: activities are centered around the daily life and household. An important requirement is that staff prepare all meals together with residents and/or their family caregivers.

3. Staff perform integrated tasks: this means that one person may fulfill multiple tasks such as medical and personal care, domestics chores and activities.

4. Residents are cared for by a small, fixed team of professional caregivers, which are part of the household.

5. Daily life is organized completely or in a large amount by residents, their family caregivers and nursing staff.

6. Archetype home: a physical setting that resembles a homelike environment. 


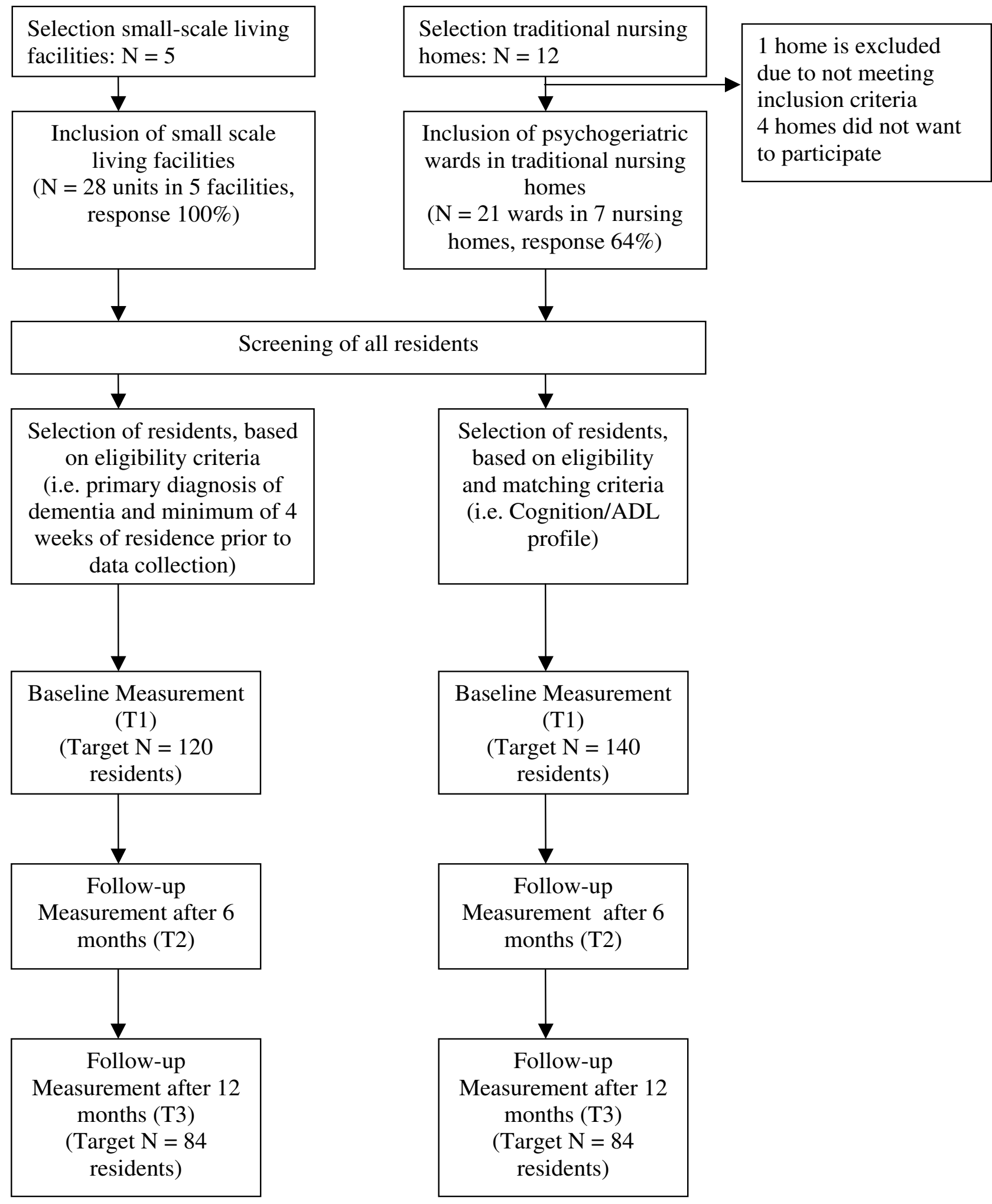

Figure I

Flow chart design and measurements. 
These criteria are based on a concept map, designed by te Boekhorst et al. (2007) [10] and on characteristics as presented in Table 1.

\section{Psychogeriatric wards in traditional nursing homes: control group}

In the Netherlands, usual care for older people with dementia consists of care in psychogeriatric wards in traditional nursing homes. Inclusion criteria for these wards are:

\section{A minimum of 20 residents per ward.}

2. Staff have differentiated tasks: their main tasks entail medical and personal care for residents. Other tasks, such as domestic chores and (social) activities are provided by other specialized disciplines.

3. Residents and their family members have little control over the organization of daily life within the ward. Daily life is mainly organized around the routines of the nursing home.

\section{Measures}

Table 2 presents all outcome and additional measures, their operationalization and timing of measurements.

\section{Residents}

The primary outcome measure for residents is quality of life (QoL), as assessed by the QUALIDEM [26-28]. The QUALIDEM is a dementia-specific QoL instrument, developed for use in residential care and is rated by professional caregivers or proxies. It is a multi-dimensional scale and consists of 37 items, divided in 9 homogeneous subscales: Care relationship ( 7 items), Positive affect (6 items), Negative affect (3 items), Restless tense behavior ( 3 items), Positive self image ( 3 items), Social relations ( 6 items), Social isolation (3 items), Feeling at home (4 items) and Having something to do (2 items). Of these subscales, 6 can be used in very severe dementia (Global Deterioration Scale stage 7 [29]) using approximately half of the items [26]. Items describe observable behaviors present last week and comprises 4 response options each: never, seldom, sometimes and often. The reliability (coefficient Rho $.60-.90$ ) and validity are found to be appropriate for evaluation of interventions $[26,27]$.

Secondary outcome measures are: neuropsychiatric symptoms (Neuropsychiatric Inventory, Nursing Home version (NPI-NH) [30-33] and Cohen-Mansfield Agitation Inventory (CMAI) [34,35]), depressive symptoms (Cornell Scale for Depression in Dementia (CSDD) $[36,37]$ ) and social engagement (Index for Social Engagement (ISE), a subscale form the Resident Assessment Instrument (RAI)
Minimum Data Set (MDS, version 2.1) [38] and Revised Index for Social Engagement (RISE) [39]).

Furthermore, several health-related variables are measured: ADL-capacity (ADL-Hierarchy (ADL-H), a subscale from the RAI-MDS (versions 2.1) [40,41]), cognition (standardized Mini-Mental State Examination (MMSE) [42] and Cognitive Performance Scale (CPS), a subscale from the RAI-MDS (version 2.1) [40,43]), use of physical restraints, psychotropic medication (classified according to the anatomical therapeutic chemical (ATC) classification system [44]), use of health care services (e.g. record of visits to the nursing home physician, psychologist and physiotherapist), comorbidity (classified according to classification of diseases in nursing home patients (CvZV) [45], compatible with the international classification of diseases, version 10 (ICD-10, [46]), dementia type and stage of dementia (Global Deterioration Scale (GDS)[29]). In addition, socio-demographic variables are assessed: gender, age, length of stay and living condition prior to admission.

\section{Family caregivers}

Primary outcome measures for family caregivers are: perceived burden, involvement with care and satisfaction with care provision. Perceived burden is measured with the 'Self-Perceived Pressure from Informal Care (SPPIC)' scale, a self-reported questionnaire consisting of 9 items $[47,48]$. Items are scored at a 5-point scale and form a one-dimensional Rasch scale, varying from less pressure to more pressure. Reliability $($ Rho $=0.79)$ and validity are found satisfactory for use in evaluation of intervention. Involvement with care is assessed by a self-report questionnaire, in which family caregivers report their frequency and length of visits, activities during a visit (based on the RAI-MDS subscale activities, version 2.1) and motivation for visiting. Satisfaction with care is assessed, using a self-reported questionnaire, which comprises 27 items, regarding care provided during the last 2-4 weeks. In addition, gender, age, relationship with the resident and sense of competence (Short Sense of Competence Questionnaire (SSCQ) [49]) are measured.

\section{Nursing Staff}

Job satisfaction and work motivation are the primary outcome measures for nursing staff. These are assessed using a self-reported questionnaire, consisting of 6 items [50]. Items are measured on a 5-point Likert scale, ranging from 1 'totally disagree' to 5 'totally agree'. Secondary outcome measures are: workplace social support (8-item scale from the Job Content Questionnaire [51,52]), job autonomy (Maastricht Autonomy Questionnaire [50]) and workload [50]. Finally, background variables age, gender, education level, contract working hours per week and employment 
Table 2: Data collection: outcome, operationalization and time of measurement.

\begin{tabular}{|c|c|c|c|c|c|}
\hline \multirow{2}{*}{$\begin{array}{l}\text { Outcome measure } \\
\text { Residents }\end{array}$} & \multirow[t]{2}{*}{ Operationalization } & \multicolumn{4}{|c|}{ Time of measurement } \\
\hline & & $\mathbf{S}$ & TI & $\mathbf{T 2}$ & T3 \\
\hline \multicolumn{6}{|l|}{ Primary outcome } \\
\hline Quality of Life & QUALIDEM [26-28] & & $\mathrm{Q}$ & $\mathrm{Q}$ & Q \\
\hline \multicolumn{6}{|l|}{ Secondary outcome } \\
\hline \multirow[t]{2}{*}{ Neuropsychiatric symptoms } & NPI-NH [30-33] & & $\mathrm{Q}$ & Q & Q \\
\hline & CMAI $[34,35]$ & & $\mathrm{Q}$ & $\mathrm{Q}$ & Q \\
\hline Depression symptoms & $\operatorname{CSDD}[36,37]$ & & Q & $\mathrm{Q}$ & Q \\
\hline Social Engagement & Subscale ISE and RISE form RAI MDS [38,39] & & Q & $\mathrm{Q}$ & Q \\
\hline \multicolumn{6}{|l|}{ Additional variables } \\
\hline ADL-capacity & Subscale ADL-H from RAI MDS $[40,4 I]$ & SQ & & Q & Q \\
\hline \multirow[t]{2}{*}{ Cognition } & MMSE [42] & & Q & & \\
\hline & Subscale CPS from RAI MDS $[40,43]$ & SQ & & $\mathrm{Q}$ & Q \\
\hline Use of physical restraint & Number of times physical restraints are used & & Q & $\mathrm{Q}$ & Q \\
\hline Psychotropic medication & ATC classification system [44] & & Q & $\mathrm{Q}$ & Q \\
\hline Use of health care services & Visits to e.g. Nursing home physician, psychologist etc. & & Q & Q & Q \\
\hline Dementia type & Alzheimer's dementia Vascular dementia, Other (e.g. Parkinson's disease) & & MR & & \\
\hline Stage of dementia & GDS [29] & & Q & Q & Q \\
\hline Comorbidity & International classification of diseases, version 10 [46] & & MR & $M R$ & MR \\
\hline \multicolumn{6}{|l|}{ Socio-demographic variables } \\
\hline Age & Years & SQ & & & \\
\hline Gender & Male or Female & SQ & & & \\
\hline Length of Stay & Number of months & SQ & & & \\
\hline Living prior to admission & At home, Residential care, Regular Nursing home care, Other & SQ & & & \\
\hline
\end{tabular}

\section{Family caregivers}

Primary outcome

\begin{tabular}{lll}
\hline Involvement with care & Frequency, length, activities and motivation for visits & $\mathrm{Q}$ \\
\hline Perceived burden & SPPIC [47]
\end{tabular}


Table 2: Data collection: outcome, operationalization and time of measurement. (Continued)

\begin{tabular}{|c|c|c|c|c|}
\hline Satisfaction with care & 27 items & Q & Q & Q \\
\hline Additional variables & & Q & Q & Q \\
\hline Age & Years & Q & Q & Q \\
\hline Gender & Male or Female & Q & Q & Q \\
\hline Sense of competence & SSCQ [49] & Q & Q & Q \\
\hline Relationship with resident & E.g. Spouse, Child, Sibling or Other & Q & Q & Q \\
\hline Nursing staff & & Q & Q & Q \\
\hline Primary outcome & & Q & Q & Q \\
\hline Job satisfaction \& motivation & {$[45]$} & Q & Q & Q \\
\hline Secondary outcome & & Q & Q & Q \\
\hline Social support & Subscale from JCQ $[51,52]$ & Q & Q & Q \\
\hline Autonomy & MAQ [50] & Q & Q & Q \\
\hline Workload & {$[45]$} & Q & Q & Q \\
\hline \multicolumn{5}{|l|}{ Additional variable } \\
\hline Age & Years & Q & Q & Q \\
\hline Gender & Male or Female & Q & Q & Q \\
\hline Education level & Type of education and level (e.g. level I - 5) & Q & Q & Q \\
\hline Contract working hours & Hours & Q & Q & $\mathrm{Q}$ \\
\hline Years of employment & Years & Q & Q & Q \\
\hline \multicolumn{5}{|c|}{$\begin{array}{l}\mathrm{S}=\text { Screening, approximately one week prior to baseline measurement } \\
\mathrm{T} 1=\text { Baseline measurement } \\
\mathrm{T} 2=\text { Follow-up after } 6 \text { months } \\
\mathrm{T} 3=\text { Follow-up after } 12 \text { months } \\
\mathrm{Q}=\text { Questionnaire, } \mathrm{SQ}=\text { Screening Questionnaire, MR = Medical Record }\end{array}$} \\
\hline
\end{tabular}

years in institution type are recorded, as well as absentee rate.

\section{Process evaluation}

To investigate to what extent both types of dementia care settings are designed as they were intended, data is collected by researchers' observations and questionnaires at all three measurements. Observations regarding the selection criteria (e.g. joint household, staff tasks) are recorded in a logbook. The questionnaire comprises items relating to the organizational, social and physical environment of the unit and are measured at a 5-point Likert scale, rang- ing from 1 'not at all' to 5 'completely'. Item examples are: 'To what extent is nursing staff part of the household?' and 'To what extent resembles the design of the unit an archetype house?'.

To examine participants' satisfaction and experiences with small-scale living, self-report questionnaires (filled in by family caregivers and staff), are administered at the end of all measurements, i.e. T3. In addition, in-depth interviews are conducted with a selection of participants. 


\section{Procedure}

Data from residents, family caregivers and nursing staff are collected at three moments a baseline measurement (T1) and 6 months (T2) and 12 months (T3) after baseline. Approximately 2 weeks prior to $\mathrm{T} 1$, a screening among residents is conducted to match residents at baseline (see Figure 1). The managing directors of the nursing homes and small-scale living facilities all provide consent to conduct the study. Written informed consent is obtained for all residents by their registered legal representative before participation. In addition, written informed consent is obtained for family caregivers and nursing staff in order to participate in the study.

\section{Screening}

The screening procedure to match residents at baseline, consists of 2 MDS subscales to assess cognition (CPS) and ADL-capacity (ADL-H) $[40,41,43]$. In addition, age, gender, length of stay and living condition prior to submission are measured. All residents in small-scale living facilities and psychogeriatric wards are assessed by the registered nurse (RN) of their unit. Cognition and ADLscores are both dichotomized. Cut-off points are based on previous studies $[38,53]$. For cognition, the three lowest scores (i.e. 4, 5 and 6) are combined as a relatively low level of performance (category '-'); the remaining scores (i.e. 0 - 3) form a relatively high level of performance (category '+'). For ADL, the 4 lowest scores (i.e. 3 - 6) are considered as a relatively low level of functioning (category ''). The other 3 scores (i.e. 0, 1 and 2) form a relatively high level of functioning (category '+'). Then, a cognition/ADL profile was constructed for each resident. Based on the profile of residents in small-scale living facilities, residents in psychogeriatric wards in traditional nursing homes with a relatively similar profile are recruited. This procedure is conducted to enhance comparability of groups at baseline with respect to cognition and ADL-capacity.

\section{Data collection}

The primary outcome measure for residents, quality of life (QUALIDEM), is assessed by 2 registered nurses (RNs) or certified nursing assistants (CNAs), as well as by residents' main family caregiver. Neuropsychiatric symptoms (NPI and CMAI), social engagement (ISE and RISE), ADLcapacity (ADL-H), cognition (CPS), use of physical restraints and use of services are assessed by RNs and CNAs. The nursing home physician or a psychologist administer the GDS, MMSE and CSDD. In addition, data regarding diagnosis and type of dementia, comorbidity and medication use are derived from medical records, as provided by the nursing home physician. Outcomes regarding family caregivers and nursing staff are based on self-report questionnaires.

\section{Sample size considerations}

Sample size calculations are based on the primary outcome measure for residents, that is QoL, as measured by the QUALIDEM [26-28]. Using an effect size $(\delta)$ of 0.33 , a significance level $\alpha$ of 0.05 (two sided) and a power of $90 \%, 84$ residents are needed in each group. Based on previous research, the drop-out rate for residents in smallscale facilities appears to be lower than those in traditional nursing homes [17]. Taking these drop-out rates into account, we aim at including 120 residents in smallscale living facilities at baseline and 140 in traditional nursing homes to have a sufficient number of residents after 12 months (see also Figure 1).

\section{Statistical Analysis}

Descriptive statistics are computed to describe background variables and characteristics of all participants, i.e. residents, family caregivers and staff. Baseline variables will be compared to investigate the comparability of residents at baseline. Multivariate regression analyses will be applied to estimate the differences in outcomes over time. Data will be analyzed according to the intention-to-treat principle, i.e. including all participants with valid data, regardless of whether they remained in the setting in which they were measured at baseline. In addition, ontreatment analyses will be performed, to investigate effects on participants who remained in the same care setting during all three measurements. In all analyses there will be correction for potential baseline differences. Dropouts, relocations and losses to follow-up will be described. In addition, subgroup analyses will be performed to investigate participants' characteristics, who gain more benefits from small-scale living facilities than others. Data collected during the process evaluation will be mainly analyzed using descriptive techniques.

\section{Study Progress}

Screening and inclusion of residents, family caregivers and professional caregivers started in April 2008 and will end in December 2008. Baseline measurements also started in April 2008. Follow-up measurements are planned for October 2008 - May 2009 and April December 2009. In October 2008, baseline measurements have been performed for 106 residents living in small-scale living facilities and 93 residents living in psychogeriatric wards. In addition, 171 family caregivers are included ( 91 from small-scale living facilities and 80 from psychogeriatric wards) and 134 nursing staff members (71 in small-scale living and 63 from psychogeriatric wards). Dissemination of results is planned for 2010 .

\section{Discussion}

This paper presents the design of a longitudinal, quasiexperimental study to investigate the effects of small-scale living facilities for older people with dementia. Although 
some challenges concerning this design exist, it is currently the most feasible method to assess the effects of this relatively new dementia care setting.

Randomization in this study is difficult to realize due to ethical and practical drawbacks. Institutional care for people with dementia is seen in the Netherlands as a home for life. As a consequence, residents and their family members, together with clinicians, decide which accommodation suits their own wishes and beliefs best. This makes a random allocation of residents to a dementia care setting complicated, as seen in a study by Maas and Buckwalter (1990), reported in Saxton et al. (1998) [15,54]. Maas and Buckwalter tried to randomly assign residents to nursing home or special care unit, but family members had problems with accepting a random group allocation. In addition, it could take several years to acquire a moderate sample size of residents in small scale living facilities by using random assignment of residents. In the Netherlands, traditional nursing homes outnumber small scale living facilities and the latter seem to have a lower turnover rate [17], which makes random assignment difficult to realize.

To prevent selection bias, we have used a matching procedure in this study to enhance comparability of resident groups at baseline, with respect to cognition and ADLcapacity. We consider cognition and functional capacity as most important characteristics for matching, since these appear strongly related to dementia severity [55], especially discriminating between moderate and severe dementia [56]. A previous study has shown that residents living in small-scale living facilities had a higher cognitive and functional status at baseline, compared to those in regular psychogeriatric wards [17]. This emphasizes the need for creating comparable groups at baseline in order to study effects of the dementia care setting. Furthermore, the environment of both dementia care settings is well documented during the process evaluation, using registration, observation, questionnaires and in-depth interviews. As a result, differences and similarities between the two settings can be taken into account during the interpretation of results.

\section{Competing interests}

The authors declare that they have no competing interests.

\section{Authors' contributions}

All authors critically reviewed the manuscript, read and approved the final manuscript. HV, EvR, SMGZ, GIJMK and JPHH are involved in the study design. TA gave advices on the statistical analysis and sample size calculations.

\section{Acknowledgements}

This study is funded by Maastricht University, the Province of Limburg, MeanderGroep Zuid-Limburg, Orbis Medisch en Zorgconcern, Sevagram, Vivre and Zorggroep Noord-Limburg.

\section{References}

I. Ferri CP, Prince M, Brayne C, Brodaty H, Fratiglioni L, Ganguli M, Hall $K$, Hasegawa $K$, Hendrie $H$, Huang $Y$, et al.: Global prevalence of dementia: a Delphi consensus study. Lancet 2005, 366:2112-2117.

2. Verbeek H, van Rossum E, Zwakhalen SMG, Kempen GIJM, Hamers JPH: Small, homelike care environments for older people with dementia: an overview of the literature. International Psychogeriatrics in press.

3. Briller SH, Calkins M: Defining Place-Based Models of Care: Conceptualizing Care Settings as Home, Resort or Hospital. Alzheimer's Care Quarterly 2000, I:17-23.

4. Marshall M, Archibald C: Long-stay care for people with dementia: recent innovations. Reviews in Clinical Gerontology 1998, 8:33I-343.

5. Finnema E, Droes RM, Ribbe M, van Tilburg W: A review of psychosocial models in psychogeriatrics: implications for care and research. Alzheimer Dis Assoc Disord 2000, 14:68-80.

6. Taft LB, Fazio S, Seman D, Stansell J: A psychosocial model of dementia care: theoretical and empirical support. Arch Psychiatr Nurs 1997, I I:13-20.

7. Moise $P$, Schwarzinger $M, U m$ M: Dementia care in 9 OECD countries: A Comparative Analysis. Paris: OECD; 2004.

8. Cohen U, Weisman G: Holding on to home. Designing Environments for People with Dementia London: John Hopkins University Press; | 991.

9. Slaughter S, Calkins M, Eliasziw M, Reimer M: Measuring Physical and Social Environments in Nursing Homes for People with Middle- to Late-Stage Dementia. Journal of the American Geriatrics Society 2006, 54:|436-|44|

10. te Boekhorst S, Depla MFIA, de Lange J, Pot AM, Eefsting JA: Kleinschalig wonen voor ouderen met dementie: een begripsverheldering (Small-scale group living for elderly with dementia: a clarification). Tijdschrift voor Gerontologie en Geriatrie 2007, 38:17-26.

II. Annerstedt L: Development and consequences of group living in Sweden. A new mode of care for the demented elderly. Social Science Medicine 1993, 37:I529-1538.

12. Rabig J, Thomas W, Kane RA, Cutler LJ, McAlilly S: Radical redesign of nursing homes: applying the green house concept in Tupelo, Mississippi. Gerontologist 2006, 46:533-539.

13. Reggentin H, Dettbarn-Reggentin J: [Group homes for patients with dementia: the possibility of social interaction]. Pflege Zeitschrift 2004, 57:181-184.

14. Wimo A, Morthenson Ekelöf C: OECD case study on dementia. Sweden: Stiftelsen Stockholms läns Äldrecentrum; 2004.

15. Saxton J, Silverman M, Ricci E, Keane C, Deeley B: Maintenance of mobility in residents of an Alzheimer special care facility. International Psychogeriatrics 1998, 10:213-224.

16. Dettbarn-Reggentin J: Studie zum Einfluss von Wohngruppenmilieus auf demenziell Erkrankte in stationären Einrichtungen. (Study on the influence of environmental residential groups on demented old people in nursing home residents). Zeitschrift fur Gerontologie Geriatrie 2005, 38:95-100.

17. Depla M, te Boekhorst S: Kleinschalig wonen voor mensen met dementie: doen of laten? (Small scale living for people with dementia: do or don't?). Utrecht: Trimbos-institute; 2007.

18. Kane RA, Lum TY, Cutler LJ, Degenholtz HB, Yu T-C: Resident Outcomes in Small-House Nursing Homes: A Longitudinal Evaluation of the Initial Green House Program. Journal of the American Geriatrics Society 2007, 55:832-839.

19. Onishi J, Suzuki $Y$, Umegaki H, Endo H, Kawamura T, Imaizumi M, Iguchi A: Behavioral, psychological and physical symptoms in group homes for older adults with dementia. International Psychogeriatrics 2006, 18:75-86.

20. Ritchie K, Colvez A, Ankri J, Ledesert B, Gardent H, Fontaine A: The evaluation of long-term care for the dementing elderly: $A$ comparative study of hospital and collective non-medical care in France. International Journal of Geriatric Psychiatry 1992, 7:549-557. 
21. Andren S, Elmstahl S: Former Family Carers' Subjective Experiences of Burden: A comparison between group living and nursing home environments in one municipality in Sweden. Dementia 2002, 1:24I-254.

22. Reggentin H, Dettbarn-Reggentin J: Wohngruppen fur Menschen mit Demenz: Belastung wird durch Motivation kompensiert. (Group homes for patients with dementia: stress is compensated by motivation). Pflege Zeitschrift 2004, 57:489-492.

23. Alfredson BB, Annerstedt $L$ : Staff attitudes and job satisfaction in the care of demented elderly people: group living compared with long-term care institutions. Journal of Advanced Nursing 1994, 20:964-974.

24. Wimo A, Winblad B, Aguero-Torres H, von Strauss E: The magnitude of dementia occurrence in the world. Alzheimer Disease and Associated Disorders 2003, 17:63-67.

25. Association: AP: Diagnostic and Statistical Manual of Mental Disorders 4th edition. Washington: American Psychiatric Association; 1994.

26. Ettema TP, Droes RM, de Lange J, Mellenbergh G], Ribbe MW: QUALIDEM: development and evaluation of a dementia specific quality of life instrument. Scalability, reliability and internal structure. International Journal of Geriatric Psychiatry 2007, 22:549-556.

27. Ettema TP, Droes RM, de Lange J, Mellenbergh GJ, Ribbe MW: QUALIDEM: development and evaluation of a dementia specific quality of life instrument-validation. International Journal of Geriatric Psychiatry 2007, 22:424-430.

28. Ettema TP, de Lange J, Droes RM, Mellenbergh D, Ribbe M: Handleiding Qualidem. Een meetinstrument Kwaliteit van Leven bij mensen met dementie in verpleeg- en verzorgingshuizen, versie I. Utrecht: Trimbos instituut; 2005.

29. Reisberg B, Ferris SH, de Leon MJ, Crook T: The Global Deterioration Scale for assessment of primary degenerative dementia. Am J Psychiatry 1982, I39(9): I 136-II 39.

30. Cummings JL, Mega M, Gray K, Rosenberg-Thompson S, Carusi DA Gornbein J: The Neuropsychiatric Inventory: comprehensive assessment of psychopathology in dementia. Neurology 1994 44:2308-23। 4 .

3I. Wood S, Cummings JL, Hsu MA, Barclay T, Wheatley MV, Yarema $\mathrm{KT}$, Schnelle JF: The use of the neuropsychiatric inventory in nursing home residents. Characterization and measurement. Am J Geriatr Psychiatry 2000, 8:75-83.

32. Kat MG, de Jonghe JFM, Aalten P, Kalisvaart CJ, Dröes RM, Verhey FRJ: Neuropsychiatric symptoms of dementia: psychometric aspects of the Neuropsychiatric Inventory (NPI) Dutch version. Tijdschr Gerontol Geriatr 2002, 33: I 50-155.

33. Lange RT, Hopp GA, Kang N: Psychometric properties and factor structure of the Neuropsychiatric Inventory Nursing Home version in an elderly neuropsychiatric population. Int J Geriatr Psychiatry 2004, 19(5):440-448.

34. de Jonghe JFM: Factor structure and validity of the Dutch version of the Cohen-Mansfield Agitation Inventory (CMAI-D). J Am Geriatr Soc 1996, 44:888-889.

35. Cohen-Mansfield J, Billig N: Agitated behavior in the elderly I. Conceptual review. J Am Geriatr Soc 1986, 34:7II-72I.

36. Alexopoulos GS, Abrams RC, Young RC, Shamoian CA: Cornell Scale for Depression in Dementia. Biol Psychiatry 1988, 23:27I-284.

37. Droes RM: Cornell Scale for Depression in Dementia. Nederlandse vertaling. Amsterdam: Vrije Universiteit, vakgroep psychiatrie; 1993.

38. Mor V, Branco K, Fleishman J, Hawes C, Phillips C, Morris J, Fries B: The structure of social engagement among nursing home residents. J Gerontol B Psychol Sci Soc Sci 1995, 50:PI-P8.

39. Gerritsen DL, Steverink N, Frijters DH, Hirdes JP, Ooms ME, Ribbe MW: A revised Index for Social Engagement for long-term care. J Gerontol Nurs 2008, 34:40-48.

40. Gerritsen D, Ooms ME, Steverink N, Frijters DHM, Bezemer D, Ribbe M: Drie nieuwe observatieschalen in het verpleeghuis: schalen uit het Resident Assessment Instrument voor Activiteiten van het Dagelijks Leven, cognitie en depressie. Tijdschr Gerontol Geriatr 2004, 35:55-64.

41. Morris JN, Fries BE, Morris SA: Scaling ADLs within the MDS. J Gerontol A Biol Sci Med Sci 1999, 54:M546-M553.

42. Folstein MF, Folstein SE, McHugh PR: A practical method for grading the cognitive status of patients for the clinician. Journal of Psychiatric Research 1975, 12:189-198.
43. Morris JN, Fries BE, Mehr DR, Hawes C, Phillips C, Mor V, Lipsitz LA: MDS Cognitive Performance Scale. J of Gerontology MEDICAL SCIENCES 1994, 49:MI74-MI82.

44. WHO: Anatomical Therapeutic Chemical (ATC) classification index including defined daily doses (DDDs) for plain substances. Oslo: World Health Organization Collaborating Centre for Drug Statistics Methodology; 1997.

45. Sig NVVA: Classificatie van ziekten voor de verpleeghuisgeneeskunde, standaard. Utrecht 1995

46. International classification of diseases, version 10 [http://
] www.who.int/classifications/icd/en/]

47. Pot AM, van-Dyck R, Deeg DJ: Ervaren druk door informele zorg. Constructie van een schaal [Perceived stress caused by informal caregiving. Construction of a scale]. Tijdschrift voor Gerontologie en Geriatrie 1995, 26:214-219.

48. Pot AM, Deeg DJ, van Dyck R, Jonker C: Psychological distress of caregivers: the mediator effect of caregiving appraisal. Patient Educ Couns 1998, 34(I):43-5I.

49. Vernooij-Dassen MJ, Felling AJ, Brummelkamp E, Dauzenberg MG, Bos GA van den, Grol R: Assessment of caregiver's competence in dealing with the burden of caregiving for a dementia patient: a Short Sense of Competence Questionnaire (SSCQ) suitable for clinical practice. J Am Geriatr Soc 1999 , 47:256-257.

50. de Jonge J: Job autonomy, well-being and health. Rijksuniversiteit Limburg; 1995.

5I. de Jonge J, Reuvers MMEN, Houtman ILD, Bongers PM, Kompier MAJ: Linear and nonlinear relations between psychosocial job characteristics, subjective outcomes, and sickness absence: Baseline results form SMASH. Journal of Occupational Health Psychology 2000, 5:256-268.

52. Karasek RAJ: Job Content Instrument: Questionnaire and user's guide. Los Angeles: University of Southern California, Department of Industrial and Systems Engineering; 1985.

53. Achterberg W, Pot AM, Kerkstra A, Ooms M, Muller M, Ribbe M: The effect of depression on social engagement in newly admitted Dutch nursing home residents. The Gerontologist 2003, 43:213-218.

54. Maas ML, Buckwalter KC: Final report: Nursing evaluation research: Alzheimer's care unit. lowa city, IA: University of lowa College of Nursing; 1990.

55. Mohs RC, Schmeidler J, Aryan M: Longitudinal studies of cognitive, functional and behavioural change in patients with Alzheimer's disease. Stat Med 2000, I 9 (I I-I 2): I 40I-I 409.

56. Steen JT van der, Volicer L, Gerritsen DL, Kruse RL, Ribbe MW, Mehr DR: Defining severe dementia with the Minimum Data Set. Int J Geriatr Psychiatry 2006, 2 I ( I I): $1099-1106$.

\section{Pre-publication history}

The pre-publication history for this paper can be accessed here:

http://www.biomedcentral.com/1471-2318/9/3/prepub

Publish with Bio Med Central and every scientist can read your work free of charge

"BioMed Central will be the most significant development for disseminating the results of biomedical research in our lifetime. "

Sir Paul Nurse, Cancer Research UK

Your research papers will be:

- available free of charge to the entire biomedical community

- peer reviewed and published immediately upon acceptance

- cited in PubMed and archived on PubMed Central

- yours - you keep the copyright
BioMedcentral 